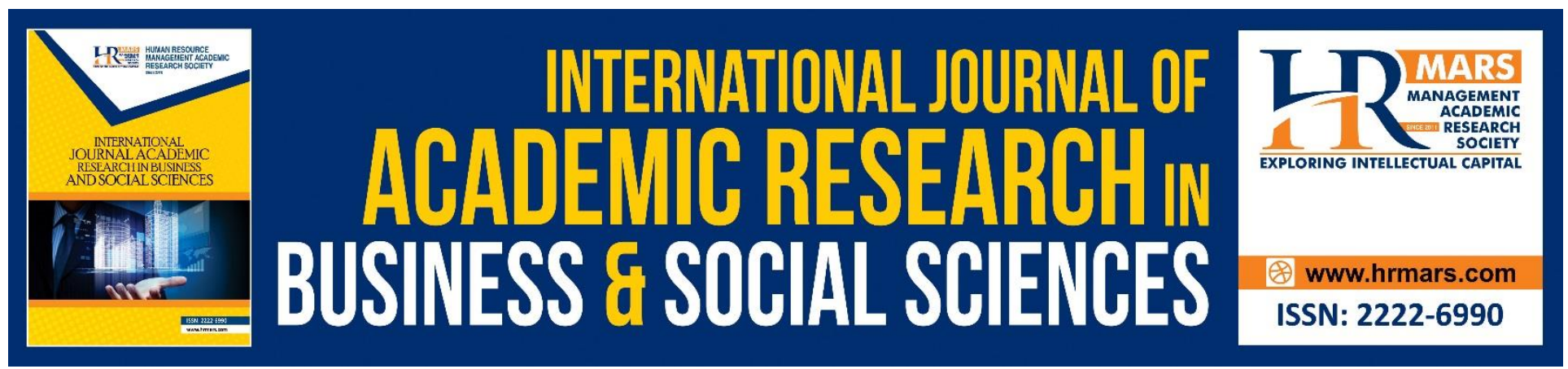

\title{
The Effects of Push-Up Training on Muscular Strength and Muscular Endurance
}

\section{Sadzali Hassan}

To Link this Article: http://dx.doi.org/10.6007/IJARBSS/v8-i11/4940

DOI: $10.6007 /$ IJARBSS/v8-i11/4940

Received: 29 Oct 2018, Revised: 21 Nov 2018, Accepted: 10 Dec 2018

Published Online: 12 Dec 2018

In-Text Citation: (Hassan, 2018)

To Cite this Article: Hassan, S. (2018). The Effects of Push-Up Training on Muscular Strength and Muscular Endurance. International Journal of Academic Research in Business and Social Sciences, 8(11), 660-665.

Copyright: (C) 2018 The Author(s)

Published by Human Resource Management Academic Research Society (www.hrmars.com)

This article is published under the Creative Commons Attribution (CC BY 4.0) license. Anyone may reproduce, distribute, translate and create derivative works of this article (for both commercial and non-commercial purposes), subject to full attribution to the original publication and authors. The full terms of this license may be seen at: http://creativecommons.org/licences/by/4.0/legalcode

Vol. 8, No. 11, 2018, Pg. 660 - 665

Full Terms \& Conditions of access and use can be found at http://hrmars.com/index.php/pages/detail/publication-ethics 


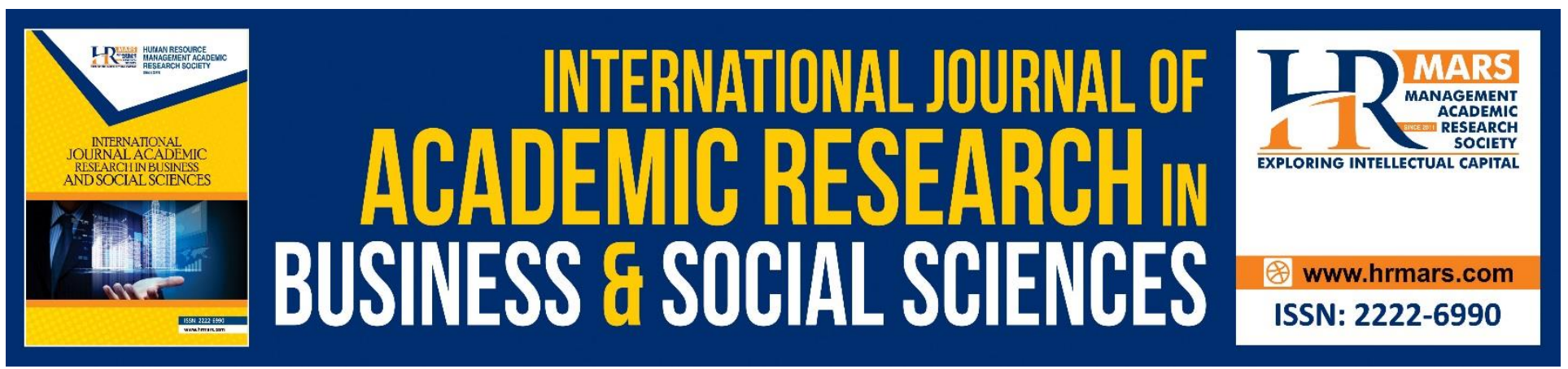

\title{
The Effects of Push-Up Training on Muscular Strength and Muscular Endurance
}

\author{
Sadzali Hassan \\ Faculty of Sports Science \& Coaching, Universiti Pendidikan Sultan Idris, Malaysia \\ Email: sadzali@fsskj.upsi.edu.my
}

\begin{abstract}
The objective of this study is to determine and compare the effects of traditional push up and plyometric push up on muscular strength and muscular endurance performance. Twenty-one male students of Universiti Pendidikan Sultan Idris were involved in this study. Subjects were divided into three groups; i) normal push up, ii) power push up and iii) control group. Participants need to perform push up training twice a week based on the groups for four weeks. Handgrip dynamometer test was conducted to measure muscular strength while one minute push up test was conducted to measure muscular endurance. Results showed that plyometric push up are more effective compared to normal push up in increasing muscular strength and muscular endurance.
\end{abstract}

\section{INTRODUCTION}

Push up is one of the basic and most common exercises for the human body. The push up is performed with the purpose of increasing strength and hypertrophy of upper extremity musculature. Push up is not only great for the chest, but do a tremendous job of defining the triceps, shoulders and torso. Push up will improve muscular endurance within the upper body, strengthen both muscles and bones, and create lean muscle mass that raises metabolism. The main muscles involved when doing push-up are pectoralis major, deltoid and triceps (Freeman, Karpowicz, Gray, \& Mcgill, 2006; Haff \& Triplett, 2015; Sandhu, Mahajan, \& Shenoy, 2008; Youdas et al., 2010).

This exercise is popular because it can be performed without any additional tools and the intensity can be altered with several variations. Additionally, push-up can also be used for assessment of muscular endurance of the upper body (Fielitz, Coelho, Horne, \& Brechue, 2016; Mak et al., 2010).

During the eccentric phase push up, the motion of the shoulder joint is a combination of extension and horizontal extension, and the corresponding movement at the shoulder girdle is adduction, downward rotation, and reduction of lateral tilt, which is accompanied by the movement of elbow flexion. During the concentric phase, the motion of the shoulder joint is typically a combination of flexion and horizontal flexion, and the corresponding movement at the shoulder girdle is abduction, upward rotation, and lateral tilt, which is accompanied by the movement of elbow extension. 
Despite of its popularity, lack of research had been conducted on comparing the effects of performing different kinds of push up methods on muscle strength adaptations. As different techniques of performing exercises were shown to causes different acute responses (Cogley, Archambault, Fibeger, \& Koverman, 2005; Kim, Yang, \& Lee, 2018; Nadzalan, Azmi, et al., 2018; Nadzalan, Mohamad, Low, \& Chinnasee, 2018; Nadzalan, Mohamad, Lee, Tan, et al., 2017; Nadzalan, Mohamad, Low, Ahmad, \& Waqqash, 2017; Nadzalan, Mohamad, Low, Tan, et al., 2017; Vila-Chã et al., 2017), it is believed that altering the movement techniques will cause different adaptations.

Thus, the purpose of this study is to determine and compare the effects of two main kinds of push up training; namely i) traditional push up and ii) plyometric push up on muscular strength and muscular endurance performance.

\section{METHODOLOGY}

\section{Subject}

Twenty-one male students of Universiti Pendidikan Sultan Idris were involved in this study. All participants had filled in the informed consent before involved in the study. Subjects were divided into three groups; i) normal push up, ii) power push up and iii) control group.

\section{Equipment}

Fitness mat was used as a mat for the subjects to perform the push up training. However, the usage of mat is optional. Stopwatch was used to set the time for one minute push up and one minute sit up test. Handheld dynamometer was used to examine the handgrip strength.

\section{Procedure}

Participants need to perform push up training twice a week based on the groups for four weeks.

\section{One minute push up test}

One minute push test was performed with only the hands and the toes touching the floor in the starting position. The hands should be placed on either side of the chest and the back should be kept straight. The chest should be lowered towards the floor, always to the same level each time, either till the elbows is at right angles or the chest touches the ground. The push up should be done as many times as possible until finished the one minute time. The repetitions will be counted by the instructor.

\section{Handgrip strength test}

Handgrip strength test is conducted with the subject holds the dynamometer in the hand to be tested, with the arm at right angles and the elbow by the side of the body. The handle of the dynamometer is adjusted if required - the base should rest on first metacarpal (heel of palm), while the handle should rest on middle of four fingers. When ready the subject squeezes the dynamometer with maximum isometric effort, which is maintained for about 5 seconds. No other body movement is allowed. The subject should be strongly encouraged to give a maximum effort. After finished, the instructor will take the score (Gerodimos, 2012; Nadzalan, 2013).

\section{Normal push up training}

Normal push up training was performed with only the hands and the toes touching the floor in the starting position. The hands should be placed on either side of the chest and the back should be kept straight. The chest should be lowered towards the floor, always to the same level each time, either till the elbows is at right angles or the chest touches the ground. The push up should be done as many times as possible until finished the one minute time during the training. 


\section{Plyometric push up training}

Plyometric push up training like the normal push up which only the hands and the toes touching the floor in the starting position. The hands should be placed on either side of the chest and the back should be kept straight. The chest should be lowered towards the floor, always to the same level each time, either till the elbows is at right angles or the chest touches the ground. The push up should be done as many times as possible until finished the one minute time during the training. The different between this plyometric push up and normal push up is that, the subjects need to push with power and the hands should be brought up and not touching the floor during push upward.

\section{RESULTS}

Table 1 showed the physical characteristics of subjects involved in this study.

Table 1. Physical characteristics

\begin{tabular}{ll}
\hline & Mean (SD) \\
\hline Age (years old) & $21.28(2.73)$ \\
Height $(\mathrm{cm})$ & $168.83(5.39)$ \\
Weight $(\mathrm{kg})$ & $68.19(2.74)$ \\
\hline
\end{tabular}

Table 2 showed the muscular strength and muscular endurance test score for the subjects in the preand post-test. Muscular strength was assessed by handgrip strength while muscular endurance was assessed by 1 minute push up.

Table 2. Muscular strength and endurance test score

\begin{tabular}{llcc}
\hline & & Normal push up & Plyometric push up \\
\hline 1 minute push up & Pre-test & $32.77(5.72)$ & $33.82(4.28)$ \\
& Post-test & $39.05(3.72)$ & $43.52(5.18)$ \\
& Differences & 6.28 & 9.70 \\
& Sig. within groups. & 0.001 & 0.001 \\
& Sig. between groups & & 0.01 \\
\hline Handgrip strength & Pre-test & $30.15(2.54)$ & $30.61(3.82)$ \\
& Post-test & $34.98(3.75)$ & $37.10(4.26)$ \\
& Differences & 4.83 & 6.49 \\
& Sig. within groups & 0.001 & 0.001 \\
& Sig. between groups & & 0.01 \\
\hline
\end{tabular}

\section{DISCUSSION}

The aim of this study is to determine and compare the effects of two main popular kinds of push up, normal push up and plyometric push up on muscular strength and muscular endurance. The muscular strength was assessed through the handgrip strength test while muscular endurance was assessed through 1 minute push up test. Subjects were recreationally active students from Universiti Pendidikan Sultan Idris in Malaysia.

In the 1 minute push up test, normal push up group significantly improved with 6.28 differences between pre and post-test. Plyometric push up group improved by 9.70 repetitions in the post-test compared to pre-test. Comparing the differences of repetitions number, it was found that plyometric 
push up group's improvement is significantly greater compared to normal push up group. Although the 1 minute push up test was similar to normal push up training, plyometric push up was more effective in improving the push up performance. This showed increasing the difficulty during training is more effective for performance enhancement (Nadzalan, Mohamad, Lee, \& Chinnasee, 2017; Nadzalan et al., 2018).

In the handgrip strength test, normal push up group significantly improved with $4.83 \mathrm{~kg}$ differences between pre and post-test. Plyometric push up group improved by $6.49 \mathrm{~kg}$ in the post-test compared to pre-test. Comparing the differences of grip score, it was found that plyometric push up group's improvement is significantly greater compared to normal push up group. This again showed the importance of increasing the difficulty during training is more effective for performance enhancement.

\section{CONCLUSION}

It can be seen in this study that performing an exercise with different methods will give different adaptations. Plyometric push up is more effective compared to normal push up in increasing muscular strength and muscular endurance. Therefore, physical trainers, athletes or interested individuals are encouraged to increase the difficulty of exercise during training.

\section{REFERENCES}

Cogley, R. M., Archambault, T. A., Fibeger, J. F., \& Koverman, M. M. (2005). Comparison of muscle activation using various hand positions during the push-up exercise. Journal of Strength and Conditioning Research, 19(3), 628.

Fielitz, L., Coelho, J., Horne, T., \& Brechue, W. (2016). Inter-rater reliability and intra-rater reliability of assessing the 2-minute push-up test. Military Medicine, 181(2), 167-172.

Freeman, S., Karpowicz, A., Gray, J., \& Mcgill, S. (2006). Quantifying muscle patterns and spine load during various forms of the push-up. Medicine and Science in Sports and Exercise, 38(3), 570577.

Gerodimos, V. (2012). Reliability of handgrip strength test in basketball players. Journal of Human Kinetics, 31, 25-36.

Haff, G. G., \& Triplett, N. T. (2015). Essentials of strength training and conditioning 4th edition: Human Kinetics.

Kim, Y.-S., Yang, J.-Y., \& Lee, N.-J. (2018). Electromyographic comparison of modified push-up exercise: focused on various arm position. Journal of Oil \& Applied Science, 35(1), 36-42.

Mak, K.-K., Ho, S.-Y., Lo, W.-S., Thomas, G. N., McManus, A. M., Day, J. R., \& Lam, T.-H. (2010). Healthrelated physical fitness and weight status in Hong Kong adolescents. BMC Public Health, 10(1), 88.

Nadzalan, A., Azmi, S., Mohamad, N., Low, J., Tan, K., \& Chinnasee, C. (2018). Kinematics analysis of dominant and non-dominant lower limb during step and jump forward lunge in badminton. Journal of Fundamental and Applied Sciences, 10(3S), 232-242.

Nadzalan, A., Mohamad, N., Low, J., \& Chinnasee, C. (2018). Lower body muscle activation during low load versus high load forward lunge among untrained men. Journal of Fundamental and Applied Sciences, 10(3S), 205-217. 
INTERNATIONAL JOURNAL OF ACADEMIC RESEARCH IN BUSINESS AND SOCIAL SCIENCES

Vol. 8, No. 11, Nov, 2018, E-ISSN: 2222-6990 @ 2018 HRMARS

Nadzalan, A. M. (2013). The effects of forearm position on handgrip strength. Jurnal Sains Sukan dan Pendidikan Jasmani, 2(1), 2-8.

Nadzalan, A. M., Mohamad, N. I., Lee, J. L. F., \& Chinnasee, C. (2017). The effects of step versus jump forward lunge exercise training on muscle architecture among recreational badminton players. World Applied Sciences Journal, 35(8), 1581-1587.

Nadzalan, A. M., Mohamad, N. I., Lee, J. L. F., Tan, K., Janep, M., Hamzah, S., \& Chinnasee, C. (2017). Muscle activation analysis of step and jump forward lunge among badminton players. Journal of Engineering and Science Research, 1(2), 60-65.

Nadzalan, A. M., Mohamad, N. I., Low, J. F. L., Ahmad, R., \& Waqqash, E. (2017). Fascicle behaviour analysis during forward lunge exercise: the comparisons between training loads. Journal of Fundamental and Applied Science, 9(6S), 1090-1101.

Nadzalan, A. M., Mohamad, N. I., Low, J. F. L., Malik, Z. A., Sankaravel, M., \& Chinnasee, C. (2018). The effects of step versus jump forward lunge as single exercise training on badminton specific physical abilities. International Journal of Advanced Biotechnology and Research., 9(1), 701709.

Nadzalan, A. M., Mohamad, N. I., Low, J. F. L., Tan, K., Janep, M., \& Hamzah, S. (2017). Kinetics analysis of step and jump forward lunge among badminton players. Journal of Fundamental and Applied Science, 9(6S), 1011-1023.

Sandhu, J. S., Mahajan, S., \& Shenoy, S. (2008). An electromyographic analysis of shoulder muscle activation during push-up variations on stable and labile surfaces. International Journal of Shoulder Surgery, 2(2), 30.

Vila-Chã, C., Ribeiro, L., Serra, N., Costa, M., Conceição, F., \& De Paz, J. (2017). Muscle activation levels during the Push-Up exercise on stable and unstable surfaces.

Youdas, J. W., Budach, B. D., Ellerbusch, J. V., Stucky, C. M., Wait, K. R., \& Hollman, J. H. (2010). Comparison of muscle-activation patterns during the conventional push-up and perfect. pushup $^{\mathrm{TM}}$ exercises. The Journal of Strength \& Conditioning Research, 24(12), 3352-3362. 